Sains Malaysiana 49(8)(2020): 1773-1785

http://dx.doi.org/10.17576/jsm-2020-4908-02

\title{
Quantitative Analysis of $\mathrm{NaCl}, \mathrm{NaOH}$, and $\beta$-phenylethylamine in Water using Ultraviolet Spectroscopy coupled with Partial Least Squares and Net Analyte Preprocessing
}

(Analisis Kuantitatif $\mathrm{NaCl}, \mathrm{NaOH}$ dan $\beta$-feniletilamina dalam Air menggunakan Spektroskopi Ultraungu Berganding dengan Kuasa Dua Terkecil Separa dan Prapemprosesan Analit Net)

\author{
XiAoJun TANG, ANGXIN TONG*, Feng ZHANG \& BIN WANG
}

\section{ABSTRACT}

During the quantitative analysis of $\mathrm{NaCl}, \mathrm{NaOH}$, and $\beta$-phenylethylamine (PEA) in water samples, the highly overlapped spectra of $\mathrm{NaCl}, \mathrm{NaOH}$, and PEA resulted in poor concentration prediction. Meanwhile, the original spectral data of the natural water usually contain noise and interference spectra which will definitely affect the prediction accuracy. Hence, a new quantitative analysis method, which was based on ultraviolet (UV) spectroscopy coupled with partial least squares (PLS) and net analyte preprocessing (NAP), was developed. Firstly, the PLS regression models of the calibration set were constructed by using 15 single component samples, 9 binary component samples and 25 ternary component samples. In addition, the independent test set was built up based on 34 samples to validate the prediction performance of the PLS regression models. The relative errors of prediction (REP) were both less than $3.1 \%$ for $\mathrm{NaCl}, \mathrm{NaOH}$, and PEA. And the correlation coefficients $\left(R_{\text {pred }}^{2}\right)$ of the PLS-1 and PLS-2 models were both not less than 0.98 for $\mathrm{NaCl}, \mathrm{NaOH}$, and PEA. Finally, the PLS models coupled with NAP algorithm were successfully used to make the quantitative determination of $\mathrm{NaCl}, \mathrm{NaOH}$, and PEA added into the natural water, and the mean recovery rates of $\mathrm{NaCl}, \mathrm{NaOH}$, and PEA were satisfactory (95-102\%). Therefore, UV spectroscopy coupled with PLS models and $\mathrm{NAP}$ algorithm can be considered as an effective method to determine the concentration of $\mathrm{NaCl}, \mathrm{NaOH}$ and PEA in the natural water.

Keywords: Interference spectra; natural water; net analyte preprocessing; partial least squares; ultraviolet spectroscopy

\section{ABSTRAK}

Semasa analisis kuantitatif $\mathrm{NaCl}, \mathrm{NaOH}$ dan $\beta$-feniletilamina (PEA) dalam sampel air, spektrum $\mathrm{NaCl}, \mathrm{NaOH}$ dan PEA yang sangat bertindih mengakibatkan ramalan kepekatan yang buruk. Sementara itu, data spektrum asal air semula jadi biasanya mengandungi spektrum hingar dan gangguan yang pasti akan mempengaruhi ketepatan ramalan. Oleh itu, kaedah analisis kuantitatif baru berdasarkan spektroskopi ultraungu (UV) yang berganding dengan kuasa dua terkecil separa (PLS) dan prapemprosesan analit net (NAP) telah dibentuk. Yang pertama, model regresi PLS daripada set penentukuran dihasilkan dengan menggunakan 15 sampel komponen tunggal, 9 sampel komponen dedua dan 25 sampel komponen terner. Tambahan pula, set ujian bersandar dibina berdasarkan 34 sampel untuk mengesahkan prestasi ramalan model regresi $P L S$. Ralat ramalan relatif (REP) adalah kurang daripada $3.1 \%$ bagi $\mathrm{NaCl}, \mathrm{NaOH}$ dan PEA. Dan pekali korelasi $\left(R_{\text {pred }}^{2}\right)$ kedua-dua model PLS-1 dan PLS-2 tidak kurang daripada 0.98 bagi $\mathrm{NaCl}, \mathrm{NaOH}$ dan PEA. Akhirnya, model PLS berganding dengan algoritma NAP berjaya digunakan untuk membuat penentuan kuantitatif $\mathrm{NaCl}, \mathrm{NaOH}$ dan PEA yang ditambahkan ke dalam air semula jadi dan kadar pemulihan min $\mathrm{NaCl}, \mathrm{NaOH}$ dan PEA adalah memuaskan (95-102\%). Oleh itu, spektroskopi UV yang berganding dengan model PLS dan algoritma NAP dapat dianggap sebagai kaedah yang berkesan untuk menentukan kepekatan NaCl, NaOH dan PEA dalam air semula jadi.

Kata kunci: Air semula jadi; kuasa dua terkecil separa; prapemprosesan analit net; spektrum gangguan; spektroskopi ultraungu

\section{INTRODUCTION}

$\beta$-phenylethylamine (PEA) is a very important chemical intermediate raw material, whose derivatives are widely used in medicine, chemical industry, emulsifier, and dye industry (Tyszka et al. 2019). During the synthetic process of PEA, $\mathrm{NaOH}$ is usually used as a reactant to synthetize PEA, and the final product usually contains PEA, $\mathrm{NaCl}$, and $\mathrm{NaOH}$ (Zamora et al. 2018). The discharge 
of the final product which contained $\mathrm{NaCl}, \mathrm{NaOH}$, and PEA will have a serious impact on the water quality. Frequent water pollution incidents have seriously affected the lives of residents and the development of social economy (Corredor-Santamaría et al. 2019). According to surveys by authoritative institutions in the world, $80 \%$ of all kinds of diseases are spread by drinking unsanitary water in developing countries, which causes at least 20 million deaths in the world every year (Yan et al. 2019). For this reason, it has become a major responsibility of local governments to monitor the level of pollutants in industrial wastewater discharged into the environment.

At present, the main detection technologies of PEA in water include gas chromatography (Wen et al. 2017), mass spectrometry (Moreira et al. 2019), high performance liquid chromatography (HPLC) (Li et al. 2018), thin-layer chromatography (Liu et al. 2013), ultra-performance liquid chromatography (Samkova et al. 2013) and some combined methods (viz. GC-MS (Yu et al. 2018), CE-MS/MS (Daniel et al. 2015), UPLC-TQ/ MS (Tasev et al. 2017), IC/MS (Scavnicar et al. 2018) and HPLC-MS (Lee et al. 2015). However, the above monitoring technologies of water quality existed the shortcomings of long period measurement, complex water samples pretreatment technology, a large number of chemical reagents requirement, and secondary pollution (Carre et al. 2017). Comparatively, the UV spectroscopy acquires the advantages of quick real-time detection, no chemical reagents, low cost, no secondary pollution, online and in-situ measurements. Based on these reasons, the UV spectroscopy has been widely concerned.

However, during the concentration prediction of the water samples by UV spectroscopy, one of the challenges is that the highly overlapped spectra of many compounds in water samples resulted in poor concentration prediction. Therefore, it is necessary to find a way to solve this problem. In particular, partial least squares (PLS) regression is a commonly used multivariate regression technique which can overcome the problem of highly overlapped spectra (Ye et al. 2018). The advantages of the PLS regression are that it can handle multiple responses and detect outliers (Mai et al. 2017). According to the numbers of dependent variables (single or multiple), the PLS regression model is divided into two types: the PLS regression model of the multiple variables (PLS-2) and the PLS regression model of the single variable (PLS-1) (Xia 2017). In recent years, PLS regression has been successfully applied to quantitative analysis of multiple components in many different fields (Guo et al. 2016; Lu et al. 2015; Shao et al. 2015; Subedi \& Fox 2016; Zhou et al. 2016). Meanwhile, many researchers have determined the contents of metal ions, organic pollutants, chemical oxygen demand (COD) and total organic carbon (TOC) in environmental water samples by UV spectroscopy technology and partial least square method (Hassaninejad-Darzi \& Torkamanzadeh 2016; Li et al. 2020; Liu \& Wang 2015; Moreno-Martin et al. 2018; Wang et al. 2017).
In addition, another challenge is that the original spectral data contain noise and interference spectra which will definitely affect the prediction accuracy of the measured components. In particular, the numbers of the optimum principal component for the PLS models will increase to make the model too complex. In order to solve this problem, the net analyte preprocessing (NAP) method was used to preprocess the original ultraviolet spectrum data. Goicoechea and Olivieri firstly proposed the NAP agorithm in 2001. The main idea of the NAP algorithm is to extract the spectral signal which is directly related to the spectra of the analyte and remove the useless signal, and finally the pure signal is obtained (Goicoechea \& Olivieri 2001). In recent years, the NAP algorithm has been widely used in different fields such as pharmaceutical, chemical products, and food industry (Hegazy et al. 2015; Salameh et al. 2020; Zappi et al. 2019).

However, the application of PLS models coupled with NAP algorithm is seldom studied in the natural water. Therefore, in this paper, UV spectrophotometry coupled with PLS models and NAP algorithm was used to accurately determine the concentration of $\mathrm{NaCl}$, $\mathrm{NaOH}$, and PEA in water. Firstly, the PLS models were constructed by the calibration set which consisted of 15 single component samples, 9 binary component samples and 25 ternary component samples. Then, the independent test set was set up to validate the prediction performance of the PLS models. Finally, the PLS models coupled with NAP algorithm were applied to accurately quantify the concentration of $\mathrm{NaCl}, \mathrm{NaOH}$, and PEA in the natural water. The satisfactory prediction results showed that the PLS models coupled with NAP algorithm was a promising method to determine the concentration of $\mathrm{NaCl}, \mathrm{NaOH}$ and PEA in the natural water.

\section{MATERIALS AND METHODS}

\section{APPARATUS AND SOFTWARE}

Absorption spectra were carried out using a UV-2900 spectrophotometer (Shanghai, China) which had a $\lambda$ range of 190 900 $\mathrm{nm}$ at $1 \mathrm{~nm}$ intervals. UV-2900 has two identical quartz cuvettes with a $1.0 \mathrm{~cm}$ optical path. One of the cuvettes was filled up with air which was taken as a reference cuvette and the other one was filled up with sample solutions and was taken as a sample cuvette. The spectra data were obtained by the software UV Solution3.0. The natural water sample was centrifuged by TG16 high speed centrifuge (Shanghai Lu Xiangyi Centrifuge Instrument Co. Ltd.), and the highest rotational speed of TG16 can reach $16000 \mathrm{r} / \mathrm{min}$. The PLS and NAP model program were written by MATLAB.

\section{REAGENTS AND STANDARD SOLUTIONS}

$\mathrm{NaCl}, \mathrm{NaOH}$, and PEA of analytical grade were purchased from Shaanxi Coal and Chemical Industry Group Co. Ltd. Standard solutions of $1 \mathrm{~mol} / \mathrm{L} \mathrm{NaCl}, 1 \mathrm{~mol} / \mathrm{L} \mathrm{NaOH}$, 
and $0.0312 \mathrm{~mol} / \mathrm{L}$ PEA were prepared separately through dissolving the appropriate amount of $\mathrm{NaCl}, \mathrm{NaOH}$, and PEA in the deionized water. The natural water sample was collected from Chanhe River (Qinling Mountain, Xi'an). In order to remove the impurities in the natural water, the sample was centrifuged at $5000 \mathrm{rpm}$ and filtered with filter paper.

\section{SAMPLE SOLUTIONS}

In order to obtain the calibration set, standard solutions of $\mathrm{NaCl}, \mathrm{NaOH}$, and PEA were extracted into a volumetric flask and diluted with deionized water, respectively. And then 49 samples which consisted of 15 single component samples, 9 binary component samples and 25 ternary component samples were prepared. In order to verify the obtained PLS calibration model, an independent test set including 34 samples which consisted of one to three components was prepared using the standard solutions. Finally, in order to test the predictive performance of the optimized PLS models in the natural water samples, 24 mixed samples which contained 9 single-component samples, 6 binary mixtures and 9 ternary mixtures were added into the natural samples.

\section{SPECTRAL DATA ANALYSIS WITH PLS AND NAP} ALGORITHM

As can be seen from Figure 1, the spectra of $\mathrm{NaCl}$, $\mathrm{NaOH}$, and PEA overlapped with each other extensively. If univariate analysis was adopted, it will inevitably result in relatively poor analysis results. Therefore, in order to overcome such seriously spectral overlapping, multivariate calibration methods like PLS must be employed.

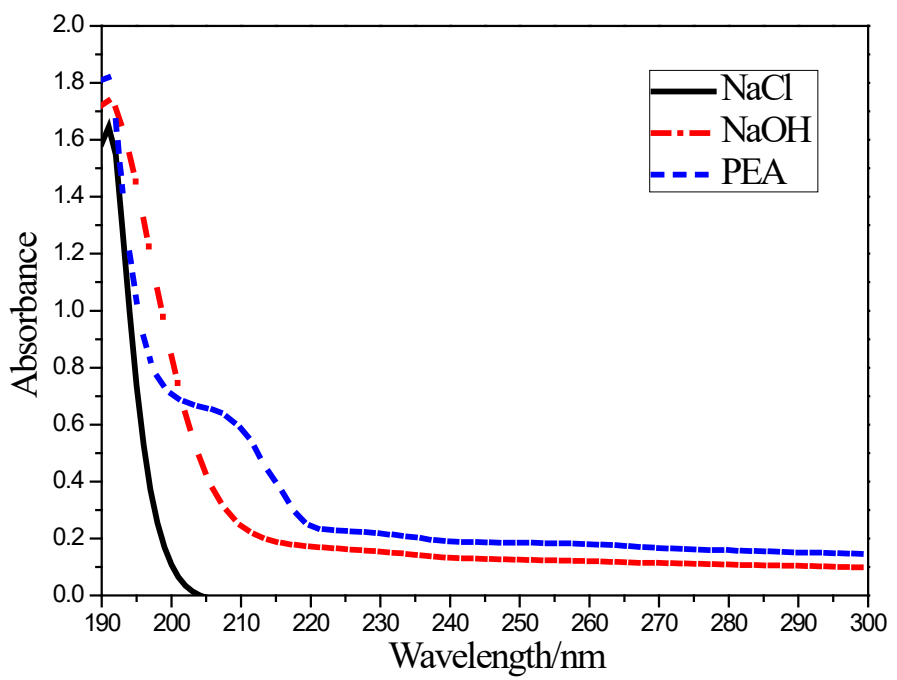

FIGURE 1. Absorption spectra of $2.04 \times 10^{-3} \mathrm{~mol} / \mathrm{L} \mathrm{NaCl}$ (black line), $8.61 \times 10^{-4} \mathrm{~mol} / \mathrm{L} \mathrm{NaOH}$ (red line) and $5.15 \times 10^{-5} \mathrm{~mol} / \mathrm{L}$ PEA (blue line)

The basic principle of the PLS algorithm has been presented by Mai et al. (2017). In order to evaluate the predictive abilities of the PLS model, the relative error of the calibration set (REC), the root mean squared error of cross-validation (RMSECV), the correlation coefficients $\left(R_{c}^{2}\right)$, the relative error of the prediction (REP), the root mean squared error of prediction (RMSEP) and the correlation coefficient $\left(R_{\text {pred }}^{2}\right)$ are calculated according to the description of Xia (2017).

NAP is based on Goicoechea's net analyte signal theory and is mainly used to remove interference spectra in the natural water (Goicoechea \& Olivieri 2001). The basic idea of the NAP algorithm is to extract the net analyte signal in the original spectral matrix by spatial orthogonal method. The specific principle of NAP algorithm is as follows:

During the process of pretreating the natural water samples, $X(n \times m)$ is the original spectral matrix of the natural water samples, and $Y(n \times p)$ is the actual concentration matrix of components in the natural water. $\mathrm{X}(\mathrm{n} \times \mathrm{m})$ can be expressed by the following formula:

$$
X=X_{S C}+X_{-S C}
$$


where $\mathrm{X}_{\mathrm{SC}}$ is the spectral matrix which consists of the absorbance spectra of $\mathrm{NaCl}, \mathrm{NaOH}$, and PEA in the natural water, and $\mathrm{X}_{-\mathrm{SC}}$ is the interference spectral matrix in the natural water.

In order to get $X_{-S C}$, the orthogonal projection transform from $X$ to $Y$ is set up. Therefore. $X_{-S C}$ can be calculated by the following formula:

$$
X_{-S C}=\left\lfloor I-Y_{n \times p}\left(Y_{n \times p}{ }^{T} Y_{n \times p}\right)^{-1} Y_{n \times p}{ }^{T}\right\rfloor X
$$

The matrix $F_{\text {NAP }}$ which is orthogonal to $X_{-S C}$ is constructed, then both sides of equation (1) is multiplied by the matrix $\mathrm{F}_{\mathrm{NAP}}$. Therefore, (1) can be simplified to the following equation:

$$
X F_{N A P}=X_{S C} F_{N A P}
$$

where $F_{N A P}=I-U^{T} I$ is a unit matrix, and $U(J \times A)$ is composed of the eigenvectors of the squared matrix $(X$ - $\left.{ }_{S C}\right)^{T} X_{-S C}$. A is the optimal number of the NAP factor which is determined by the interference spectral matrix $X_{-S C}$.

Finally, the net analyte spectra matrix $X_{S C}^{*}$ is obtained which is pretreated by A factors. Therefore, the net analyte spectra matrix $X_{S C}^{*}$ can be calculated by the following equation:

$$
\begin{gathered}
X_{S C}^{*}=X F_{N A P}=X\left(I-U U^{T}\right) \\
\text { RESULTS AND DISCUSSION } \\
\text { PLS CALIBRATION MODELS FOR } \\
\text { CONCENTRATION PREDICTION }
\end{gathered}
$$

\section{RESULTS AND DISCUSSION}

\section{PLS CALIBRATION MODELS FOR CONCENTRATION PREDICTION}

In order to construct the PLS calibration models, as described, the construction of the calibration model was used 49 samples which consisted of 15 single component samples, 9 binary component samples and 25 ternary component samples. And different concentrations of the

\begin{tabular}{|c|c|c|c|c|c|c|c|}
\hline Sample no, & $\mathrm{NaCl}$ & $\mathrm{NaOH}$ & PEA & Sample no, & $\mathrm{NaCl}$ & $\mathrm{NaOH}$ & PEA \\
\hline \multicolumn{4}{|c|}{ Ternary mixtures } & \multicolumn{4}{|c|}{ Binary mixtures } \\
\hline 1 & $7.64 \times 10^{-6}$ & $3.76 \times 10^{-5}$ & $6.12 \times 10^{-7}$ & 26 & - & $3.76 \times 10^{-5}$ & $6.03 \times 10^{-6}$ \\
\hline 2 & $7.64 \times 10^{-6}$ & $1.53 \times 10^{-4}$ & $6.03 \times 10^{-6}$ & 27 & - & $1.53 \times 10^{-4}$ & $1.21 \times 10^{-5}$ \\
\hline 3 & $7.64 \times 10^{-6}$ & $5.91 \times 10^{-4}$ & $1.21 \times 10^{-5}$ & 28 & - & $5.91 \times 10^{-4}$ & $2.24 \times 10^{-5}$ \\
\hline 4 & $7.64 \times 10^{-6}$ & $8.46 \times 10^{-4}$ & $2.24 \times 10^{-5}$ & 29 & - & $8.46 \times 10^{-4}$ & $5.19 \times 10^{-5}$ \\
\hline 5 & $7.64 \times 10^{-6}$ & $1.25 \times 10^{-3}$ & $5.19 \times 10^{-5}$ & 30 & $7.64 \times 10^{-6}$ & $1.25 \times 10^{-3}$ & - \\
\hline 6 & $7.26 \times 10^{-5}$ & $3.76 \times 10^{-5}$ & $6.03 \times 10^{-6}$ & 31 & $1.75 \times 10^{-4}$ & $5.91 \times 10^{-4}$ & - \\
\hline 7 & $7.26 \times 10^{-5}$ & $1.53 \times 10^{-4}$ & $1.21 \times 10^{-5}$ & 32 & $1.78 \times 10^{-3}$ & $3.76 \times 10^{-5}$ & - \\
\hline 8 & $7.26 \times 10^{-5}$ & $5.91 \times 10^{-4}$ & $2.24 \times 10^{-5}$ & 33 & $7.26 \times 10^{-5}$ & - & $6.12 \times 10^{-7}$ \\
\hline 9 & $7.26 \times 10^{-5}$ & $8.46 \times 10^{-4}$ & $5.19 \times 10^{-5}$ & 34 & $7.82 \times 10^{-4}$ & - & $1.21 \times 10^{-5}$ \\
\hline 10 & $7.26 \times 10^{-5}$ & $1.25 \times 10^{-3}$ & $6.12 \times 10^{-7}$ & \multicolumn{4}{|c|}{ Single component solutions } \\
\hline 11 & $1.75 \times 10^{-4}$ & $3.76 \times 10^{-5}$ & $1.21 \times 10^{-5}$ & 35 & $7.64 \times 10^{-6}$ & - & - \\
\hline 12 & $1.75 \times 10^{-4}$ & $1.53 \times 10^{-4}$ & $2.24 \times 10^{-5}$ & 36 & $7.26 \times 10^{-5}$ & - & - \\
\hline 13 & $1.75 \times 10^{-4}$ & $5.91 \times 10^{-4}$ & $5.19 \times 10^{-5}$ & 37 & $1.75 \times 10^{-4}$ & - & - \\
\hline 14 & $1.75 \times 10^{-4}$ & $8.46 \times 10^{-4}$ & $6.12 \times 10^{-7}$ & 38 & $7.82 \times 10^{-4}$ & - & - \\
\hline 15 & $1.75 \times 10^{-4}$ & $1.25 \times 10^{-3}$ & $6.03 \times 10^{-6}$ & 39 & $1.78 \times 10^{-3}$ & - & - \\
\hline 16 & $7.82 \times 10^{-4}$ & $3.76 \times 10^{-5}$ & $2.24 \times 10^{-5}$ & 40 & - & $3.76 \times 10^{-5}$ & - \\
\hline 17 & $7.82 \times 10^{-4}$ & $1.53 \times 10^{-4}$ & $5.19 \times 10^{-5}$ & 41 & - & $1.53 \times 10^{-4}$ & - \\
\hline 18 & $7.82 \times 10^{-4}$ & $5.91 \times 10^{-4}$ & $6.12 \times 10^{-7}$ & 42 & - & $5.91 \times 10^{-4}$ & - \\
\hline 19 & $7.82 \times 10^{-4}$ & $8.46 \times 10^{-4}$ & $6.03 \times 10^{-6}$ & 43 & - & $8.46 \times 10^{-4}$ & - \\
\hline 20 & $7.82 \times 10^{-4}$ & $1.25 \times 10^{-3}$ & $1.21 \times 10^{-5}$ & 44 & - & $1.25 \times 10^{-3}$ & - \\
\hline 21 & $1.78 \times 10^{-3}$ & $3.76 \times 10^{-5}$ & $5.19 \times 10^{-5}$ & 45 & - & - & $6.12 \times 10^{-7}$ \\
\hline 22 & $1.78 \times 10^{-3}$ & $1.53 \times 10^{-4}$ & $6.12 \times 10^{-7}$ & 46 & - & - & $6.03 \times 10^{-6}$ \\
\hline 23 & $1.78 \times 10^{-3}$ & $5.91 \times 10^{-4}$ & $6.03 \times 10^{-6}$ & 47 & - & - & $1.21 \times 10^{-5}$ \\
\hline 24 & $1.78 \times 10^{-3}$ & $8.46 \times 10^{-4}$ & $1.21 \times 10^{-5}$ & 48 & - & - & $2.24 \times 10^{-5}$ \\
\hline 25 & $1.78 \times 10^{-3}$ & $1.25 \times 10^{-3}$ & $2.24 \times 10^{-5}$ & 49 & - & - & $5.19 \times 10^{-5}$ \\
\hline
\end{tabular}
calibration model were listed in Table 1.

TABLE 1 . Concentrations $(\mathrm{mol} / \mathrm{L})$ for the calibration samples in the calibration set 
The numbers of the optimum principal component used in the PLS- 1 and PLS- 2 models were obtained by the method of cross validation, and the results were shown in Figure 2(a) and 2(b). As observed by Figure 2(a) and 2(b), the numbers of the optimum principal component of the PLS-1 and PLS- 2 models for $\mathrm{NaOH}$ and PEA were both 8 . The number of the optimum principal component of the PLS- 1 model for $\mathrm{NaCl}$ was 8 and the PLS- 2 model was 9 . The detailed results of the PLS-1 and PLS-2 calibration models were listed in Table 2 which included the number of the optimum principal component, RMSECV, REC, and $R_{c}^{2}$. According to the results listed in Table 2, satisfactory results had been obtained for $\mathrm{NaCl}, \mathrm{NaOH}$, and PEA in the PLS-1 and
PLS-2 models which proved the effectiveness of the PLS calibration models.

In addition, the residual values of the calibration model were obtained by the formula: $\delta_{i}=y_{\text {act }, i}-y_{\text {pred }, i}$, where $\mathrm{y}_{\text {act, }}$ represents the actual measured value and $\mathrm{y}_{\text {pred, }}$ represents the predicted value by the PLS models in the $\mathrm{i}^{\text {th }}$ sample.

Figure 3 was obtained by plotting the residual values vs. the concentration of $\mathrm{NaCl}, \mathrm{NaOH}$, and PEA by the PLS- 1 and PLS- 2 models. As observed by Figure 3 , the residual values obtained from the PLS-1 and PLS-2 models were both distributed around the X-axis, indicating that the residual errors were uniformly distributed around the zero error.

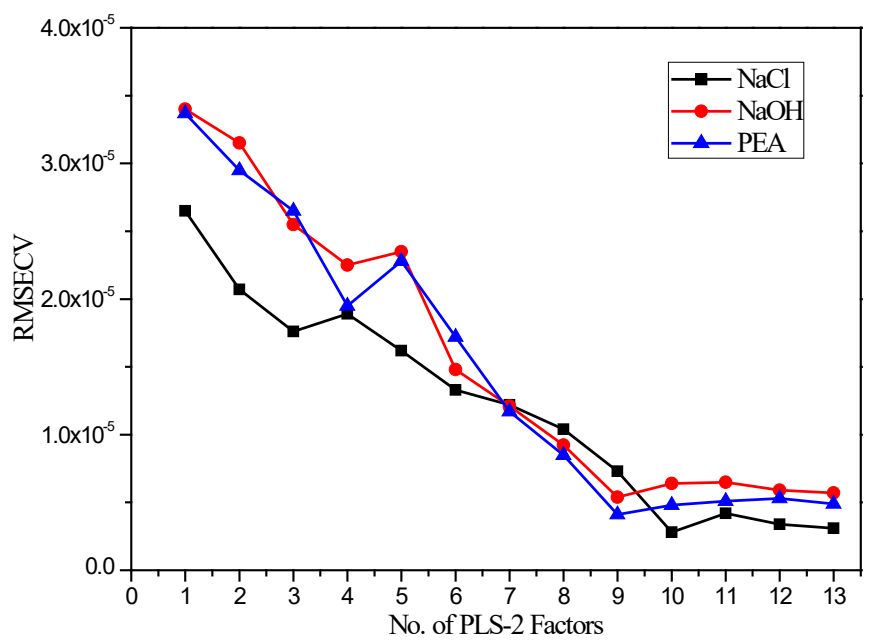

(a)

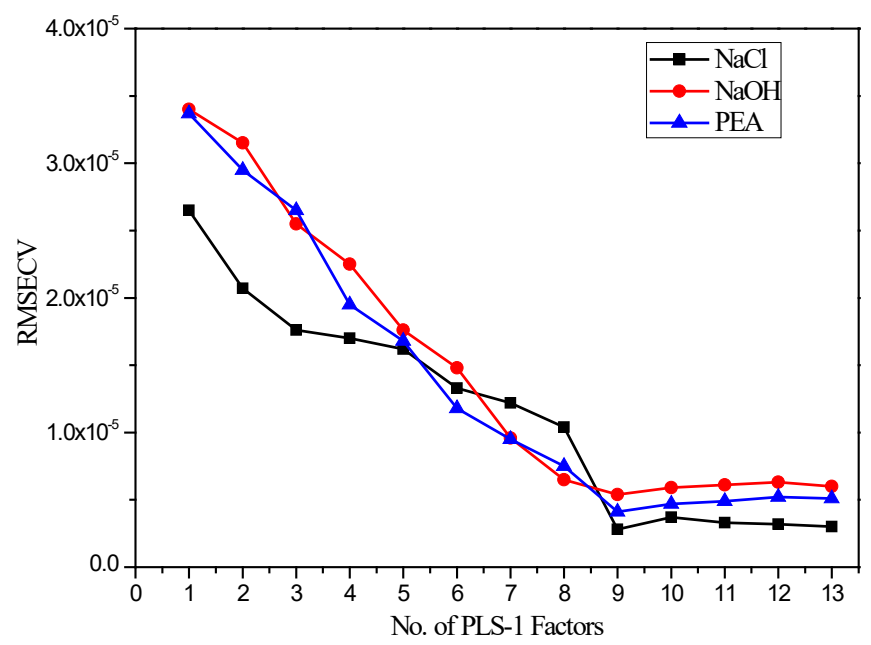

(b)

FIGURE 2. (a) Plot of RMSECV value vs. the number of factors in PLS-2 regression. (b) Plot of RMSECV value vs. the number of factors in PLS-1 regression 


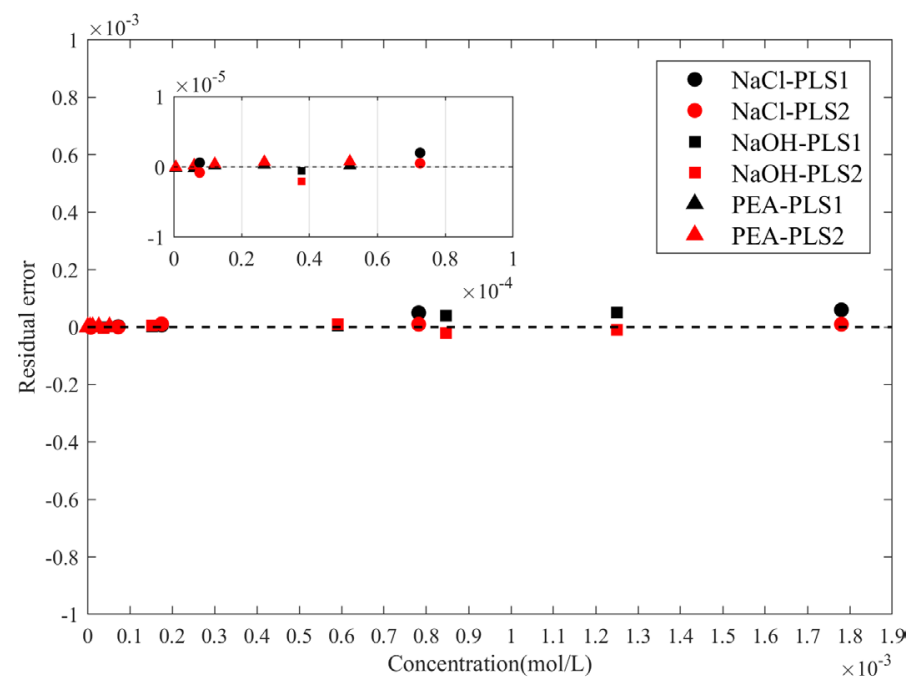

FIGURE 3. Residual errors of the PLS-1 and PLS-2 models vs. concentration plots for the three components of the calibration model samples

TABLE 2. Statistical parameters of $\mathrm{NaCl}, \mathrm{NaOH}$ and PEA in the calibration set

\begin{tabular}{ccccccccc}
\hline & \multicolumn{3}{c}{ PLS-1 } & \multicolumn{3}{c}{ PLS-2 } \\
\hline & Factors & REC (\%) & RMSECV & $\mathrm{R}_{\mathrm{c}}{ }^{2}$ & Factors & REC (\%) & RMSECV & $\mathrm{R}_{\mathrm{c}}{ }^{2}$ \\
$\mathrm{NaCl}$ & 8 & 2.63 & $4.42 \times 10^{-5}$ & 0.9926 & 9 & 2.26 & $3.96 \times 10^{-5}$ & 0.9907 \\
$\mathrm{NaOH}$ & 8 & 1.53 & $3.75 \times 10^{-5}$ & 0.9886 & 8 & 1.38 & $3.43 \times 10^{-5}$ & 0.9903 \\
$\mathrm{PEA}$ & 8 & 2.74 & $1.60 \times 10^{-6}$ & 0.9902 & 8 & 2.92 & $1.04 \times 10^{-6}$ & 0.9893 \\
\hline
\end{tabular}

VALIDATION OF THE PLS MODELS BY THE INDEPENDENT TEST SET

Although the PLS calibration models had achieved good results in the concentration prediction of the calibration set, the prediction of the independent test set should be performed in order to further validate the performance of the PLS calibration models. Therefore, 34 samples of the independent test set were constructed to validate the PLS- 1 and PLS- 2 models. The actual measured value and the predicted value of $\mathrm{NaCl}, \mathrm{NaOH}$, and PEA by the PLS models were listed in Table 3. It can be seen from the Table 3 that the actual measured value was very close to the predicted value obtained by the PLS- 1 and PLS- 2 models.

Similarly, as observed by Figure 4, the residual values obtained from the independent test set were also distributed around the $\mathrm{X}$-axis, proving the validity of the PLS-1 and PLS-2 models which were constructed. Therefore, it is feasible to simultaneously determine the concentration of pollutants in water by the PLS models.

TABLE 3. Determination of $\mathrm{NaCl}, \mathrm{NaOH}$ and PEA (mol/L) in the independent test set

\begin{tabular}{ccccccccc}
\hline \multicolumn{3}{c}{ Concentration (mol/L) } & \multicolumn{3}{c}{ PLS-1 prediction } & \multicolumn{3}{c}{ PLS-2 prediction } \\
\hline \multicolumn{1}{c}{$\mathrm{NaCl}$} & $\mathrm{NaOH}$ & $\mathrm{PEA}$ & $\mathrm{NaCl}$ & $\mathrm{NaOH}$ & $\mathrm{PEA}$ & $\mathrm{NaCl}$ & $\mathrm{NaOH}$ & PEA \\
\hline \multicolumn{7}{c}{ Ternary mixtures } \\
\hline $7.13 \times 10^{-5}$ & $3.81 \times 10^{-5}$ & $6 \times 10^{-7}$ & $7.09 \times 10^{-5}$ & $4.08 \times 10^{-5}$ & $7.61 \times 10^{-7}$ & $7.20 \times 10^{-5}$ & $4.01 \times 10^{-5}$ & $6.20 \times 10^{-7}$ \\
$7.13 \times 10^{-5}$ & $5.82 \times 10^{-4}$ & $1.13 \times 10^{-5}$ & $7.11 \times 10^{-5}$ & $5.79 \times 10^{-4}$ & $1.14 \times 10^{-5}$ & $7.22 \times 10^{-5}$ & $5.76 \times 10^{-4}$ & $1.12 \times 10^{-5}$
\end{tabular}




\begin{tabular}{|c|c|c|c|c|c|c|c|c|}
\hline $7.13 \times 10^{-5}$ & $8.61 \times 10^{-4}$ & $3.21 \times 10^{-5}$ & $7.10 \times 10^{-5}$ & $8.55 \times 10^{-4}$ & $3.20 \times 10^{-5}$ & $7.19 \times 10^{-5}$ & $8.51 \times 10^{-4}$ & $3.17 \times 10^{-5}$ \\
\hline $7.13 \times 10^{-5}$ & $1.13 \times 10^{-3}$ & $5.15 \times 10^{-5}$ & $7.09 \times 10^{-5}$ & $1.12 \times 10^{-3}$ & $5.12 \times 10^{-5}$ & $7.18 \times 10^{-5}$ & $1.12 \times 10^{-3}$ & $5.08 \times 10^{-5}$ \\
\hline $5.24 \times 10^{-4}$ & $3.81 \times 10^{-5}$ & $1.13 \times 10^{-5}$ & $5.20 \times 10^{-4}$ & $3.92 \times 10^{-5}$ & $1.15 \times 10^{-5}$ & $5.19 \times 10^{-4}$ & $3.95 \times 10^{-5}$ & $1.11 \times 10^{-5}$ \\
\hline $5.24 \times 10^{-4}$ & $5.82 \times 10^{-4}$ & $3.21 \times 10^{-5}$ & $5.22 \times 10^{-4}$ & $5.81 \times 10^{-4}$ & $3.22 \times 10^{-5}$ & $5.22 \times 10^{-4}$ & $5.78 \times 10^{-4}$ & $3.19 \times 10^{-5}$ \\
\hline $5.24 \times 10^{-4}$ & $8.61 \times 10^{-4}$ & $5.15 \times 10^{-5}$ & $5.21 \times 10^{-4}$ & $8.57 \times 10^{-4}$ & $5.19 \times 10^{-5}$ & $5.21 \times 10^{-4}$ & $8.53 \times 10^{-4}$ & $5.12 \times 10^{-5}$ \\
\hline $5.24 \times 10^{-4}$ & $1.13 \times 10^{-3}$ & $6 \times 10^{-7}$ & $5.26 \times 10^{-4}$ & $1.09 \times 10^{-3}$ & $7.86 \times 10^{-7}$ & $5.23 \times 10^{-4}$ & $1.14 \times 10^{-3}$ & $6.22 \times 10^{-7}$ \\
\hline $9.85 \times 10^{-4}$ & $3.81 \times 10^{-5}$ & $3.21 \times 10^{-5}$ & $9.78 \times 10^{-4}$ & $3.74 \times 10^{-5}$ & $3.19 \times 10^{-5}$ & $9.74 \times 10^{-4}$ & $3.89 \times 10^{-5}$ & $3.19 \times 10^{-5}$ \\
\hline $9.85 \times 10^{-4}$ & $5.82 \times 10^{-4}$ & $5.15 \times 10^{-5}$ & $9.80 \times 10^{-4}$ & $5.83 \times 10^{-4}$ & $5.21 \times 10^{-5}$ & $9.80 \times 10^{-4}$ & $5.79 \times 10^{-4}$ & $5.14 \times 10^{-5}$ \\
\hline $9.85 \times 10^{-4}$ & $8.61 \times 10^{-4}$ & $6 \times 10^{-7}$ & $9.82 \times 10^{-4}$ & $8.58 \times 10^{-4}$ & $6.72 \times 10^{-7}$ & $9.78 \times 10^{-4}$ & $8.55 \times 10^{-4}$ & $6.15 \times 10^{-7}$ \\
\hline $9.85 \times 10^{-4}$ & $1.13 \times 10^{-3}$ & $1.13 \times 10^{-5}$ & $9.81 \times 10^{-4}$ & $1.17 \times 10^{-3}$ & $1.12 \times 10^{-5}$ & $9.81 \times 10^{-4}$ & $1.15 \times 10^{-3}$ & $1.14 \times 10^{-5}$ \\
\hline $1.67 \times 10^{-3}$ & $3.81 \times 10^{-5}$ & $5.15 \times 10^{-5}$ & $1.66 \times 10^{-3}$ & $3.89 \times 10^{-5}$ & $5.09 \times 10^{-5}$ & $1.65 \times 10^{-3}$ & $3.92 \times 10^{-5}$ & $5.18 \times 10^{-5}$ \\
\hline $1.67 \times 10^{-3}$ & $5.82 \times 10^{-4}$ & $6 \times 10^{-7}$ & $1.69 \times 10^{-3}$ & $5.80 \times 10^{-4}$ & $6.58 \times 10^{-7}$ & $1.63 \times 10^{-3}$ & $5.81 \times 10^{-4}$ & $6.13 \times 10^{-7}$ \\
\hline $1.67 \times 10^{-3}$ & $8.61 \times 10^{-4}$ & $1.13 \times 10^{-5}$ & $1.72 \times 10^{-3}$ & $8.63 \times 10^{-4}$ & $1.12 \times 10^{-5}$ & $1.69 \times 10^{-3}$ & $8.57 \times 10^{-4}$ & $1.13 \times 10^{-5}$ \\
\hline $1.67 \times 10^{-3}$ & $1.13 \times 10^{-3}$ & $3.21 \times 10^{-5}$ & $1.62 \times 10^{-3}$ & $1.15 \times 10^{-3}$ & $3.21 \times 10^{-5}$ & $1.71 \times 10^{-3}$ & $1.10 \times 10^{-3}$ & $3.22 \times 10^{-5}$ \\
\hline \multicolumn{9}{|c|}{ Binary mixtures } \\
\hline $7.13 \times 10^{-5}$ & - & $6 \times 10^{-7}$ & $7.10 \times 10^{-5}$ & $3.08 \times 10^{-6}$ & $6.53 \times 10^{-7}$ & $7.17 \times 10^{-5}$ & $2.54 \times 10^{-6}$ & $6.24 \times 10^{-7}$ \\
\hline $5.24 \times 10^{-4}$ & - & $1.13 \times 10^{-5}$ & $5.21 \times 10^{-4}$ & $3.06 \times 10^{-6}$ & $1.10 \times 10^{-5}$ & $5.22 \times 10^{-4}$ & $2.52 \times 10^{-6}$ & $1.10 \times 10^{-5}$ \\
\hline $9.85 \times 10^{-4}$ & $3.81 \times 10^{-5}$ & - & $9.83 \times 10^{-4}$ & $3.86 \times 10^{-5}$ & $2.67 \times 10^{-7}$ & $9.82 \times 10^{-4}$ & $3.84 \times 10^{-5}$ & $2.85 \times 10^{-8}$ \\
\hline $1.67 \times 10^{-3}$ & $5.82 \times 10^{-4}$ & - & $1.69 \times 10^{-3}$ & $5.79 \times 10^{-4}$ & $2.72 \times 10^{-7}$ & $1.68 \times 10^{-3}$ & $5.83 \times 10^{-4}$ & $2.84 \times 10^{-8}$ \\
\hline- & $8.61 \times 10^{-4}$ & $3.21 \times 10^{-5}$ & $2.06 \times 10^{-7}$ & $8.62 \times 10^{-4}$ & $3.24 \times 10^{-5}$ & $1.59 \times 10^{-6}$ & $8.59 \times 10^{-4}$ & $3.18 \times 10^{-5}$ \\
\hline- & $1.13 \times 10^{-3}$ & $5.15 \times 10^{-5}$ & $1.96 \times 10^{-7}$ & $1.14 \times 10^{-3}$ & $5.12 \times 10^{-5}$ & $1.60 \times 10^{-6}$ & $1.15 \times 10^{-3}$ & $5.19 \times 10^{-5}$ \\
\hline \multicolumn{9}{|c|}{ Single-component solutions } \\
\hline $7.13 \times 10^{-5}$ & - & - & $7.12 \times 10^{-5}$ & $3.05 \times 10^{-6}$ & $2.67 \times 10^{-7}$ & $7.12 \times 10^{-5}$ & $2.53 \times 10^{-6}$ & $2.83 \times 10^{-8}$ \\
\hline $5.24 \times 10^{-4}$ & - & - & $5.22 \times 10^{-4}$ & $3.06 \times 10^{-6}$ & $2.68 \times 10^{-7}$ & $5.24 \times 10^{-4}$ & $2.55 \times 10^{-6}$ & $2.85 \times 10^{-8}$ \\
\hline $9.85 \times 10^{-4}$ & - & - & $9.84 \times 10^{-4}$ & $3.08 \times 10^{-6}$ & $2.64 \times 10^{-7}$ & $9.83 \times 10^{-4}$ & $2.54 \times 10^{-6}$ & $2.86 \times 10^{-8}$ \\
\hline $1.67 \times 10^{-3}$ & - & - & $1.66 \times 10^{-3}$ & $3.09 \times 10^{-6}$ & $2.70 \times 10^{-7}$ & $1.66 \times 10^{-3}$ & $2.51 \times 10^{-6}$ & $2.84 \times 10^{-8}$ \\
\hline- & $3.81 \times 10^{-5}$ & - & $2.03 \times 10^{-7}$ & $3.83 \times 10^{-5}$ & $2.71 \times 10^{-7}$ & $1.59 \times 10^{-6}$ & $3.82 \times 10^{-5}$ & $2.82 \times 10^{-8}$ \\
\hline- & $5.82 \times 10^{-4}$ & - & $2.05 \times 10^{-7}$ & $5.80 \times 10^{-4}$ & $2.69 \times 10^{-7}$ & $1.55 \times 10^{-6}$ & $5.82 \times 10^{-4}$ & $2.87 \times 10^{-8}$ \\
\hline- & $8.61 \times 10^{-4}$ & - & $2.08 \times 10^{-7}$ & $8.60 \times 10^{-4}$ & $2.65 \times 10^{-7}$ & $1.56 \times 10^{-6}$ & $8.60 \times 10^{-4}$ & $2.85 \times 10^{-8}$ \\
\hline- & $1.13 \times 10^{-3}$ & - & $2.06 \times 10^{-7}$ & $1.12 \times 10^{-3}$ & $2.66 \times 10^{-7}$ & $1.59 \times 10^{-6}$ & $1.15 \times 10^{-3}$ & $2.83 \times 10^{-8}$ \\
\hline- & - & $6 \times 10^{-7}$ & $2.01 \times 10^{-7}$ & $3.08 \times 10^{-6}$ & $6.41 \times 10^{-7}$ & $1.58 \times 10^{-6}$ & $2.49 \times 10^{-6}$ & $6.14 \times 10^{-7}$ \\
\hline- & - & $1.13 \times 10^{-5}$ & $1.97 \times 10^{-7}$ & $3.10 \times 10^{-6}$ & $1.12 \times 10^{-5}$ & $1.61 \times 10^{-6}$ & $2.56 \times 10^{-6}$ & $1.15 \times 10^{-5}$ \\
\hline- & - & $3.21 \times 10^{-5}$ & $1.96 \times 10^{-7}$ & $3.12 \times 10^{-6}$ & $3.23 \times 10^{-5}$ & $1.59 \times 10^{-6}$ & $2.55 \times 10^{-6}$ & $3.20 \times 10^{-5}$ \\
\hline- & - & $5.15 \times 10^{-5}$ & $2.06 \times 10^{-7}$ & $3.06 \times 10^{-6}$ & $5.14 \times 10^{-5}$ & $1.62 \times 10^{-6}$ & $2.54 \times 10^{-6}$ & $5.17 \times 10^{-5}$ \\
\hline
\end{tabular}




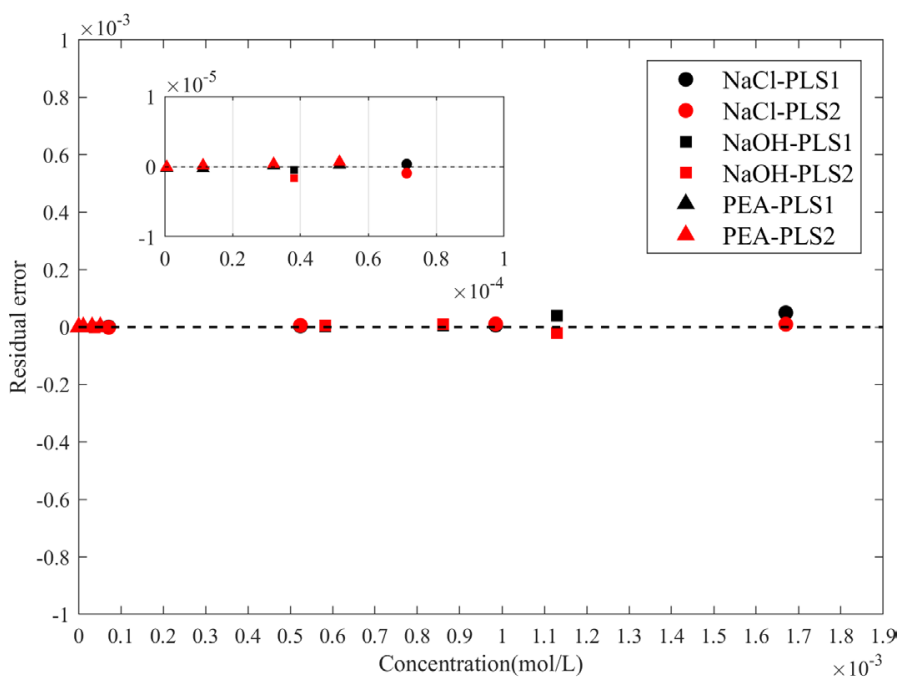

FIGURE 4. Residual errors of the PLS-1 and PLS-2 models vs. concentration plots for the three components of the independent test samples

The parameters of the PLS- 1 and PLS- 2 models for the independent test set were listed in Table 4 which included the RMSEP, REP, $R_{\text {pred }}^{2}$ and the mean recovery. As can be seen from the Table 4, the RMSEP values of $\mathrm{NaCl}, \mathrm{NaOH}$, and PEA for the PLS-1 and PLS2 models were lower than $4.10 \times 10^{-5}, 3.60 \times 10^{-5}$, and $1.50 \times 10^{-6}$, respectively. The $R_{\text {pred }}{ }^{2}$ values of $\mathrm{NaCl}, \mathrm{NaOH}$, and PEA for the PLS- 1 and PLS- 2 models were higher than $0.99,0.98$, and 0.99 , respectively. Moreover, the mean recovery rates of $\mathrm{NaCl}, \mathrm{NaOH}$, and PEA for the PLS- 1 and PLS- 2 models were all close to $100 \%$. From the above results, it can be seen that the constructed PLS1 and PLS- 2 models also have a good performance in the concentration prediction of the independent test set samples.

TABLE 4. Parameters of $\mathrm{NaCl}, \mathrm{NaOH}$ and PEA in the independent test set by PLS- 1 and PLS-2 models

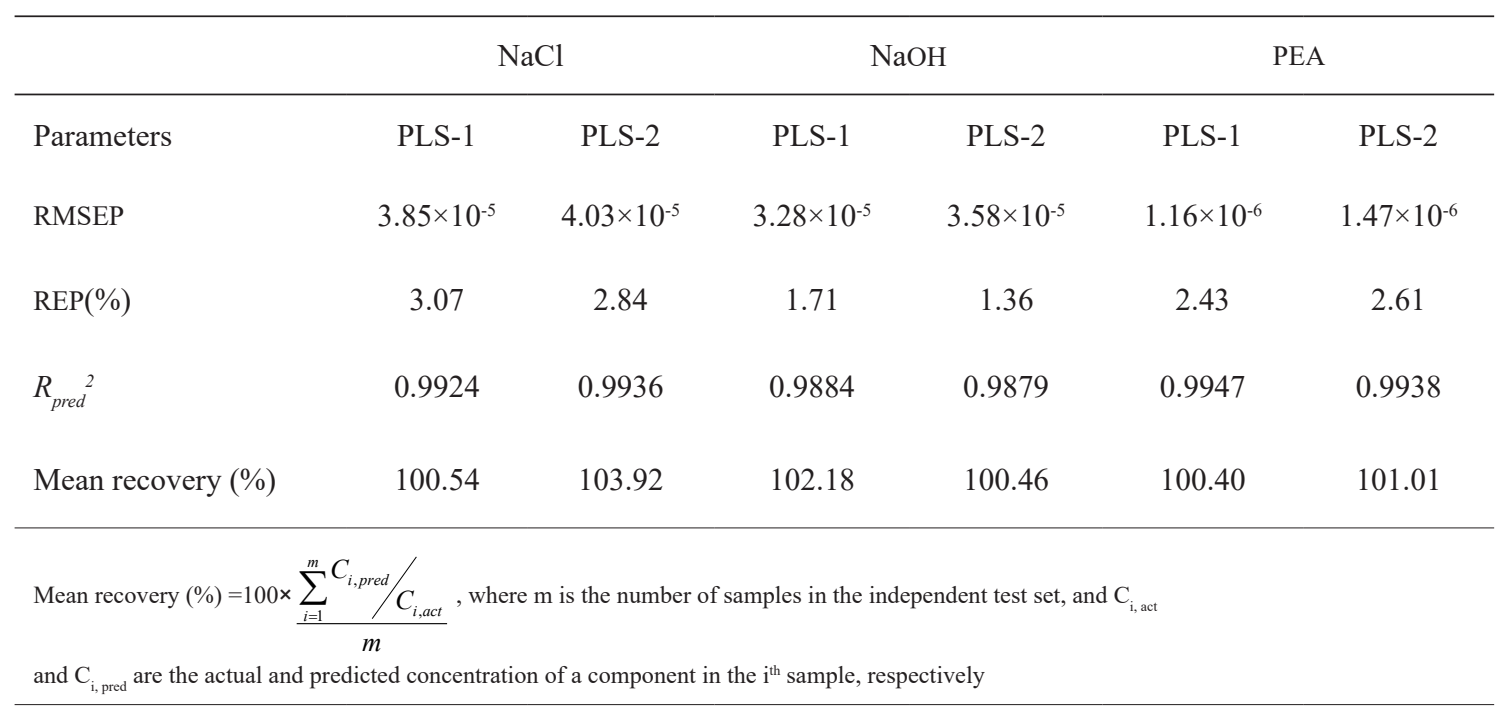


APPLICATION OF THE PLS MODEL AND NAP ALGORITHM IN THE NATURAL WATER

As described previously, 24 mixed samples which contained 9 single-component samples, 6 binary mixtures and 9 ternary mixtures were added into the natural water samples. Table 5 shows that the actual measured value and the predicted value which were pretreated by the NAP algorithm. As can be seen from the Table 5, the predicted concentration values of $\mathrm{NaCl}$,
$\mathrm{NaOH}$, and PEA were very close to the actual values. The mean recovery rates of $\mathrm{NaCl}, \mathrm{NaOH}$, and PEA were $100.57 \%, 97.24 \%$, and $96.35 \%$ in the NAP/PLS- 1 model, and $101.32 \%, 95.73 \%$, and $97.69 \%$ in the NAP/PLS-2 model, respectively. From the above results, it can be seen that the constructed NAP/PLS models had a good performance in the concentration prediction of the natural water samples.

TABLE 5. Concentration prediction of $\mathrm{NaCl}, \mathrm{NaOH}$ and PEA $(\mathrm{mol} / \mathrm{L})$ in the natural water

\begin{tabular}{|c|c|c|c|c|c|c|c|c|}
\hline \multicolumn{3}{|c|}{ Concentration $(\mathrm{mol} / \mathrm{L})$} & \multicolumn{3}{|c|}{ NAP/PLS-1 prediction } & \multicolumn{3}{|c|}{ NAP/PLS-2 prediction } \\
\hline $\mathrm{NaCl}$ & $\mathrm{NaOH}$ & PEA & $\mathrm{NaCl}$ & $\mathrm{NaOH}$ & PEA & $\mathrm{NaCl}$ & $\mathrm{NaOH}$ & PEA \\
\hline \multicolumn{9}{|c|}{ Ternary mixtures } \\
\hline $1.45 \times 10^{-3}$ & $3.47 \times 10^{-5}$ & $7.48 \times 10^{-7}$ & $1.44 \times 10^{-3}$ & $3.74 \times 10^{-5}$ & $8.51 \times 10^{-7}$ & $1.43 \times 10^{-3}$ & $3.67 \times 10^{-5}$ & $7.66 \times 10^{-7}$ \\
\hline $1.45 \times 10^{-3}$ & $4.26 \times 10^{-4}$ & $5.36 \times 10^{-6}$ & $1.46 \times 10^{-3}$ & $4.24 \times 10^{-4}$ & $5.57 \times 10^{-6}$ & $1.42 \times 10^{-3}$ & $4.22 \times 10^{-4}$ & $5.32 \times 10^{-6}$ \\
\hline $1.45 \times 10^{-3}$ & $1.15 \times 10^{-3}$ & $3.83 \times 10^{-5}$ & $1.43 \times 10^{-3}$ & $1.14 \times 10^{-3}$ & $3.82 \times 10^{-5}$ & $1.44 \times 10^{-3}$ & $1.14 \times 10^{-3}$ & $3.78 \times 10^{-5}$ \\
\hline $7.28 \times 10^{-4}$ & $4.26 \times 10^{-4}$ & $5.36 \times 10^{-6}$ & $7.22 \times 10^{-4}$ & $4.22 \times 10^{-4}$ & $5.48 \times 10^{-6}$ & $7.20 \times 10^{-4}$ & $4.23 \times 10^{-4}$ & $5.34 \times 10^{-6}$ \\
\hline $7.28 \times 10^{-4}$ & $3.47 \times 10^{-5}$ & $7.48 \times 10^{-7}$ & $7.25 \times 10^{-4}$ & $3.69 \times 10^{-5}$ & $8.46 \times 10^{-7}$ & $7.22 \times 10^{-4}$ & $3.58 \times 10^{-5}$ & $7.59 \times 10^{-7}$ \\
\hline $7.28 \times 10^{-4}$ & $1.15 \times 10^{-3}$ & $3.83 \times 10^{-5}$ & $7.24 \times 10^{-4}$ & $1.13 \times 10^{-3}$ & $3.80 \times 10^{-5}$ & $7.25 \times 10^{-4}$ & $1.13 \times 10^{-3}$ & $3.81 \times 10^{-5}$ \\
\hline $7.36 \times 10^{-6}$ & $4.26 \times 10^{-4}$ & $5.36 \times 10^{-6}$ & $7.50 \times 10^{-6}$ & $4.20 \times 10^{-4}$ & $5.42 \times 10^{-6}$ & $8.16 \times 10^{-6}$ & $4.28 \times 10^{-4}$ & $5.39 \times 10^{-6}$ \\
\hline $7.36 \times 10^{-6}$ & $1.15 \times 10^{-3}$ & $3.83 \times 10^{-5}$ & $7.47 \times 10^{-6}$ & $1.16 \times 10^{-3}$ & $3.79 \times 10^{-5}$ & $7.94 \times 10^{-6}$ & $1.17 \times 10^{-3}$ & $3.79 \times 10^{-5}$ \\
\hline $7.36 \times 10^{-6}$ & $3.47 \times 10^{-5}$ & $7.48 \times 10^{-7}$ & $7.44 \times 10^{-6}$ & $3.76 \times 10^{-5}$ & $8.43 \times 10^{-7}$ & $7.88 \times 10^{-6}$ & $3.53 \times 10^{-5}$ & $7.54 \times 10^{-7}$ \\
\hline \multicolumn{9}{|c|}{ Binary mixtures } \\
\hline $1.45 \times 10^{-3}$ & - & $7.48 \times 10^{-7}$ & $1.47 \times 10^{-3}$ & $3.08 \times 10^{-6}$ & $7.92 \times 10^{-7}$ & $1.44 \times 10^{-3}$ & $2.54 \times 10^{-6}$ & $7.56 \times 10^{-7}$ \\
\hline $7.28 \times 10^{-4}$ & $3.47 \times 10^{-5}$ & - & $7.25 \times 10^{-4}$ & $3.54 \times 10^{-5}$ & $2.67 \times 10^{-7}$ & $7.22 \times 10^{-4}$ & $3.51 \times 10^{-5}$ & $2.85 \times 10^{-8}$ \\
\hline $7.36 \times 10^{-6}$ & $4.26 \times 10^{-4}$ & - & $7.40 \times 10^{-6}$ & $4.22 \times 10^{-4}$ & $2.71 \times 10^{-7}$ & $7.75 \times 10^{-6}$ & $4.28 \times 10^{-4}$ & $2.82 \times 10^{-8}$ \\
\hline- & $1.15 \times 10^{-3}$ & $5.36 \times 10^{-6}$ & $2.06 \times 10^{-7}$ & $1.13 \times 10^{-3}$ & $5.40 \times 10^{-6}$ & $1.59 \times 10^{-6}$ & $1.12 \times 10^{-3}$ & $5.38 \times 10^{-6}$ \\
\hline- & $4.26 \times 10^{-4}$ & $3.83 \times 10^{-5}$ & $2.10 \times 10^{-7}$ & $4.23 \times 10^{-4}$ & $3.80 \times 10^{-5}$ & $1.62 \times 10^{-6}$ & $4.29 \times 10^{-4}$ & $3.80 \times 10^{-5}$ \\
\hline $7.28 \times 10^{-4}$ & - & $5.36 \times 10^{-6}$ & $7.23 \times 10^{-4}$ & $3.06 \times 10^{-6}$ & $5.39 \times 10^{-6}$ & $7.24 \times 10^{-4}$ & $2.57 \times 10^{-6}$ & $5.40 \times 10^{-6}$ \\
\hline \multicolumn{9}{|c|}{ Single-component solutions } \\
\hline $1.45 \times 10^{-3}$ & - & - & $1.46 \times 10^{-3}$ & $3.08 \times 10^{-6}$ & $2.67 \times 10^{-7}$ & $1.44 \times 10^{-3}$ & $2.54 \times 10^{-6}$ & $2.85 \times 10^{-8}$ \\
\hline $7.28 \times 10^{-4}$ & - & - & $7.26 \times 10^{-4}$ & $3.06 \times 10^{-6}$ & $2.69 \times 10^{-7}$ & $7.24 \times 10^{-4}$ & $2.56 \times 10^{-6}$ & $2.87 \times 10^{-8}$ \\
\hline $7.36 \times 10^{-6}$ & - & - & $7.39 \times 10^{-6}$ & $3.05 \times 10^{-6}$ & $2.66 \times 10^{-7}$ & $7.62 \times 10^{-6}$ & $2.57 \times 10^{-6}$ & $2.82 \times 10^{-8}$ \\
\hline- & $3.47 \times 10^{-5}$ & - & $2.06 \times 10^{-7}$ & $3.50 \times 10^{-5}$ & $2.65 \times 10^{-7}$ & $1.59 \times 10^{-6}$ & $3.50 \times 10^{-5}$ & $2.83 \times 10^{-8}$ \\
\hline- & $4.26 \times 10^{-4}$ & - & $2.07 \times 10^{-7}$ & $4.25 \times 10^{-4}$ & $2.67 \times 10^{-7}$ & $1.61 \times 10^{-6}$ & $4.27 \times 10^{-4}$ & $2.87 \times 10^{-8}$ \\
\hline- & $1.15 \times 10^{-3}$ & - & $2.05 \times 10^{-7}$ & $1.16 \times 10^{-3}$ & $2.70 \times 10^{-7}$ & $1.58 \times 10^{-6}$ & $1.13 \times 10^{-3}$ & $2.85 \times 10^{-8}$ \\
\hline- & - & $7.48 \times 10^{-7}$ & $2.08 \times 10^{-7}$ & $3.10 \times 10^{-6}$ & $7.60 \times 10^{-7}$ & $1.57 \times 10^{-6}$ & $2.52 \times 10^{-6}$ & $7.51 \times 10^{-7}$ \\
\hline- & - & $5.36 \times 10^{-6}$ & $2.02 \times 10^{-7}$ & $3.08 \times 10^{-6}$ & $5.34 \times 10^{-6}$ & $1.59 \times 10^{-6}$ & $2.54 \times 10^{-6}$ & $5.37 \times 10^{-6}$ \\
\hline- & - & $3.83 \times 10^{-5}$ & $2.06 \times 10^{-7}$ & $3.09 \times 10^{-6}$ & $3.81 \times 10^{-5}$ & $1.58 \times 10^{-6}$ & $2.51 \times 10^{-6}$ & $3.81 \times 10^{-5}$ \\
\hline
\end{tabular}


Figures 5 and 6 show the RMSEP values vs. the numbers of the PLS-2 and PLS-1 factors with different NAP factors. As can be seen from Figures 5 and 6, the numbers of the optimum principal component for the PLS models decreased gradually with the increase of NAP factors. And the numbers of the optimum principal component for the PLS models decreased one when the NAP factor increased one before the minimum value of RMSEP was obtained. During this process, the total numbers of the NAP factors and the optimum principal component factors for the PLS models remained unchanged. This indicated that some principal component factors of the model had been converted into NAP factors after the original spectra were pretreated by the NAP algorithm. The NAP algorithm can remove interference spectra in the original spectra to the greatest extent by means of spatial orthogonality. In this way, the spectra which were pretreated by NAP algorithm only contained the spectra of $\mathrm{NaCl}, \mathrm{NaOH}$, and PEA. Therefore, the NAP method did not affect the precision of the PLS models, but it greatly reduced the complexity of the PLS models.
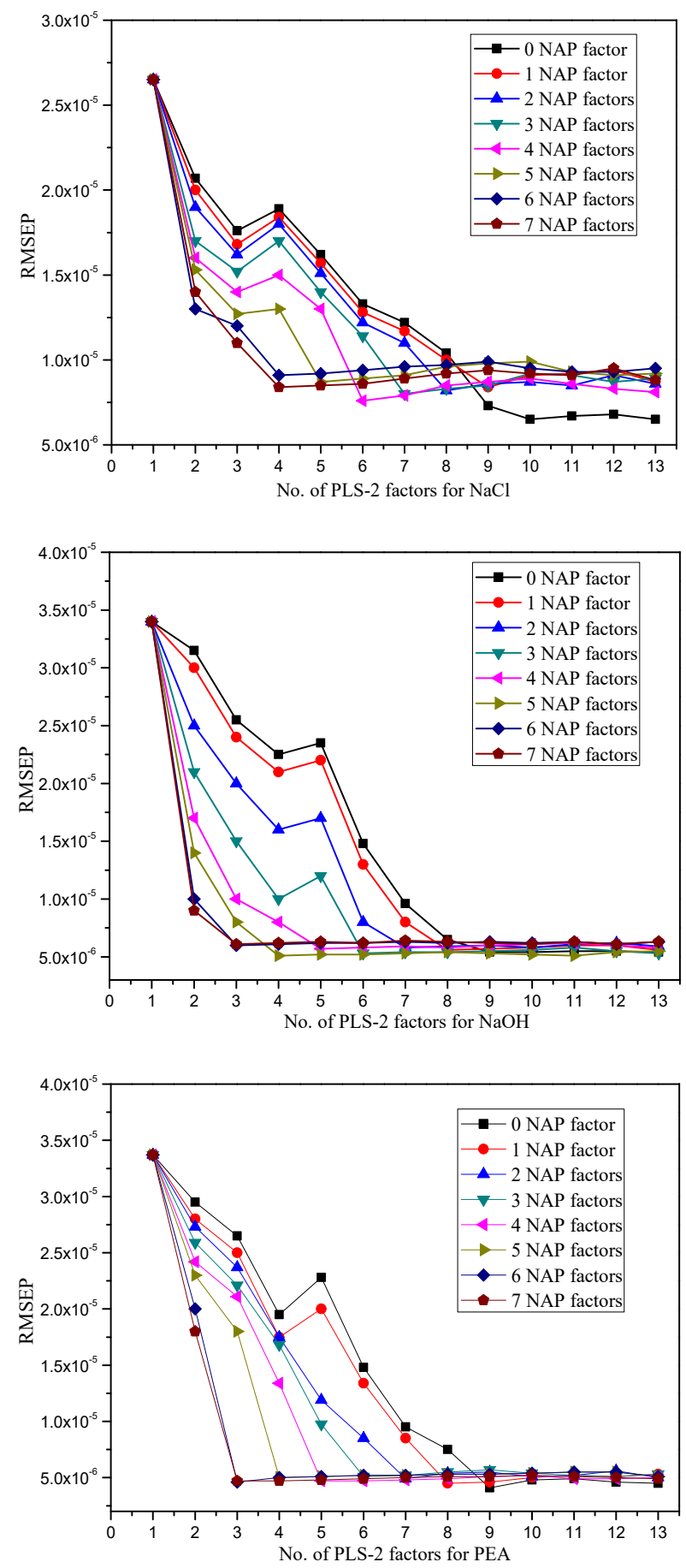

FIGURE 5. Concentration prediction of $\mathrm{NaCl}, \mathrm{NaOH}$ and PEA $(\mathrm{mol} / \mathrm{L})$ in the natural water 

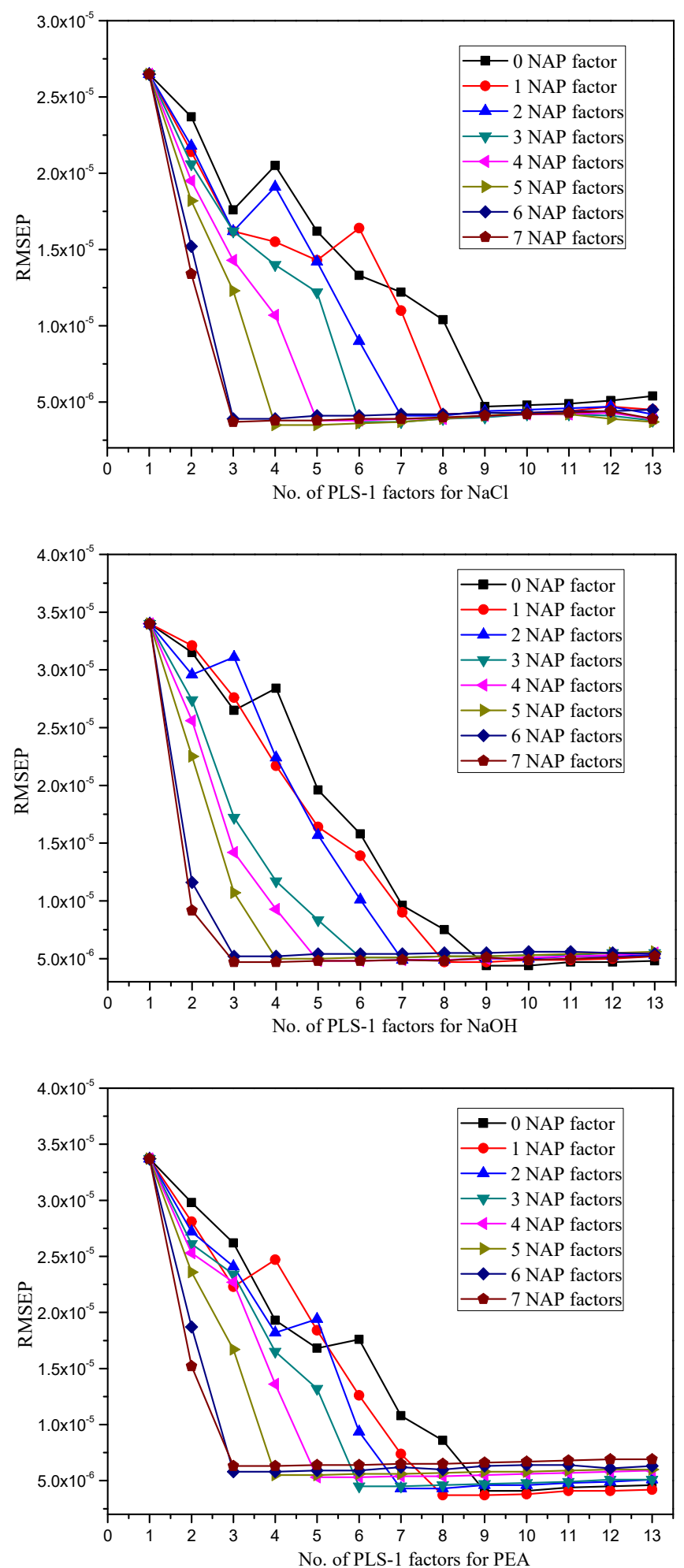

FIGURE 6. Diagram of RMSEP vs. the numbers of PLS-1 factor combined with NAP algorithm

The parameters of the PLS- 1 and PLS-2 models which were pretreated by NAP algorithm for the natural water were listed in Table 6 . As can be seen from the Table 6 , the $\mathrm{R}_{\text {cal }}{ }^{2}$ and RMSEP values of the PLS models almost had no change compared with the PLS models which were pretreated by the NAP algorithm. However, the factors of the PLS models were greatly reduced after the original spectra were pretreated by the NAP algorithm. 
TABLE 6. Parameters of the natural water spectra before and after being pretreated by NAP

\begin{tabular}{lccccccc}
\hline & & \multicolumn{3}{c}{ PLS-1 } & & \multicolumn{2}{c}{ PLS-2 } \\
\cline { 3 - 7 } Preprocessing method & Component & factors & $\mathrm{R}_{\text {cal }}^{2}$ & RMSEP & factors & $\mathrm{R}_{\text {cal }}^{2}$ & RMSEP \\
\hline & $\mathrm{NaCl}$ & 8 & 0.9902 & $3.67 \times 10^{-5}$ & 9 & 0.9884 & $3.71 \times 10^{-5}$ \\
Without preprocessing & $\mathrm{NaOH}$ & 8 & 0.9873 & $6.85 \times 10^{-5}$ & 8 & 0.9842 & $6.91 \times 10^{-5}$ \\
& $\mathrm{PEA}$ & 8 & 0.9879 & $6.72 \times 10^{-6}$ & 8 & 0.9821 & $6.65 \times 10^{-6}$ \\
$\mathrm{NAP}$ & $\mathrm{NaCl}$ & 2 & 0.9891 & $3.73 \times 10^{-5}$ & 3 & 0.9879 & $3.78 \times 10^{-5}$ \\
& $\mathrm{NaOH}$ & 2 & 0.9884 & $6.88 \times 10^{-5}$ & 2 & 0.9865 & $6.95 \times 10^{-5}$ \\
& $\mathrm{PEA}$ & 2 & 0.9784 & $6.74 \times 10^{-6}$ & 2 & 0.9837 & $6.67 \times 10^{-6}$ \\
\hline
\end{tabular}

\section{CONCLUSION}

In this study, UV spectrophotometry coupled with PLS models was successfully used to simultaneously determine the concentration of $\mathrm{NaCl}, \mathrm{NaOH}$, and PEA in the calibration set. Then the independent test set was set up to validate the effectiveness of the PLS regression models. The results indicated that PLS models had a good accuracy of concentration prediction while the spectra of $\mathrm{NaCl}, \mathrm{NaOH}$, and PEA overlapped with each other highly. The good agreement between the predicted value and the actual value indicated the validity of the PLS models for simultaneous determination of $\mathrm{NaCl}$, $\mathrm{NaOH}$, and PEA in pure samples. In order to reduce the influence of noise and impurities in the natural water, UV spectrophotometry coupled with PLS models and NAP algorithm was used to predict the concentration of 24 mixed samples which contained $\mathrm{NaCl}, \mathrm{NaOH}$, and PEA in the natural water. The results showed that the predictive effect of the natural water with the PLS models and NAP algorithm was also very satisfactory (with the mean recovery rates of $\mathrm{NaCl}, \mathrm{NaOH}$ and PEA between $95-102 \%$ ). It can be concluded that the NAP method did not affect the precision of the PLS models, but it greatly reduced the complexity of the PLS models. Therefore, UV spectrophotometry coupled with PLS models and NAP algorithm can be used as a quick, low cost and dependable analysis method to simultaneously determine the concentration of pollutants in the natural water.

\section{ACKNOWLEDGEMENTS}

The authors gratefully acknowledge financial support by The National Key Research and Development Program of China (2016YFF0102805).

\section{REFERENCES}

Carre, E., Perot, J., Jauzein, V., Lin, L.M. \& Lopez-Ferber, M. 2017. Estimation of water quality by UV/Vis spectrometry in the framework of treated wastewater reuse. Water Science and Technology 76(3): 633-641.

Corredor-Santamaría, W., Torres-Tabares, A. \& VelascoSantamaría, Y.M. 2019. Biochemical and histological alterations in Aequidens metae (Pisces, Cichlidae) and Astyanax gr. bimaculatus (Pisces, Characidae) as indicators of river pollution. Science of The Total Environment 692: 1234-1241.

Daniel, D., dos Santos, V.B., Vidal, D.T.R. \& do Lago, C.L. 2015. Determination of biogenic amines in beer and wine by capillary electrophoresis-tandem mass spectrometry. Journal of Chromatography A 1416: 121-128.

Goicoechea, H.C. \& Olivieri, A.C. 2001. A comparison of orthogonal signal correction and net analyte preprocessing methods. Theoretical and experimental study. Chemometrics and Intelligent Laboratory Systems 56(2): 73-81.

Guo, H.X., Huang, F.R., Li, Y.P., Fang, T., Zhu, S.Q. \& Chen, Z.Q. 2016. Determination of proteins in human serum by nearinfrared spectroscopy with partial least square analysis. Analytical Letters 49(18): 2964-2976.

Hassaninejad-Darzi, S.K. \& Torkamanzadeh, M. 2016. Simultaneous UV-Vis spectrophotometric quantification of ternary basic dye mixtures by partial least squares and artificial neural networks. Water Science and Technology 74(10): 2497-2504.

Hegazy, M.A.M., Abbas, S.S. \& Zaazaa, H.E. 2015. Resolution of overlapped quaternary spectral bands by net analyte signal based methods: An application to different combinations in tablets and capsules. Journal of Analytical Chemistry 70(4): 450-458.

Lee, S., Yoo, M. \& Shin, D. 2015. The identification and quantification of biogenic amines in Korean turbid rice wine, 
Makgeolli by HPLC with mass spectrometry detection. LWT-Food Science and Technology 62(1): 350-356.

Li, J., Guan, R.F., Wei, X.M., Chen, J.C., Hu, Y.Q., Liu, D.H. \& Ye, X.Q. 2018. Detection of ten biogenic amines in Chinese commercial soybean paste by HPLC. International Journal of Food Properties 21(1): 1344-1350.

Li, X.Z., Zhou, J., Tang, H., Sun, L., Cao, X.M. \& Zhang, X.S. 2020. Rapid determination of total nitrogen in aquaculture water based on ultraviolet spectroscopy. Spectroscopy and Spectral Analysis 40(1): 195-201.

Liu, F., Du, L.H., Xu, W.Y., Wang, D.Y., Zhang, M.H., Zhu, Y.Z. \& Xu, W.M. 2013. Production of tyramine by Enterococcus faecalis strains in water-boiled salted duck. Journal of Food Protection 76(5): 854-859.

Liu, X.H. \& Wang, L.L. 2015. Use of multivariate calibration models based on UV-Vis spectra for seawater quality monitoring in Tianjin Bohai Bay, China. Water Science and Technology 71(10): 1444-1450.

Lu, Y.Z., Du, C.W., Yu, C.B. \& Zhou, J.M. 2015. Determination of nitrogen in rapeseed by fourier transform infrared photoacoustic spectroscopy and independent component analysis. Analytical Letters 48(7): 1150-1162.

Mai, W., Zhang, J.F., Zhao, X.M., Li, Z. \& Xu, Z.W. 2017. Partial least squares regression calibration of an ultraviolet-visible spectrophotometer for measurements of chemical oxygen demand in dye wastewater. Journal of Applied Spectroscopy 84(5): 804-810.

Moreira, A.M.D., de Oliveira, H.L., Allochio, J.F., Florez, D.H.A., Borges, M.M.C., Lacerda, V., Romao, W. \& Borges, K.B. 2019. NBOMe compounds: An overview about analytical methodologies aiming their determination in biological matrices. TrAC-Trends in Analytical Chemistry 114: 260277.

Moreno-Martin, G., Leon-Gonzalez, M.E. \& Madrid, Y. 2018. Simultaneous determination of the size and concentration of AgNPs in water samples by UV-vis spectrophotometry and chemometrics tools. Talanta 188: 393-403.

Salameh, B.A., Al-Degs, Y.S., Abu Safieh, K.A. \& ALZghool, A.W. 2020. Novel application of multivariate standard addition method based on net analyte signal for quantification of artificial sweeteners in complex food matrices. Journal of Food Measurement and Characterization 14(1): 78-87.

Samkova, E., Dadakova, E. \& Pelikanova, T. 2013. Changes in biogenic amine and polyamine contents in smear-ripened cheeses during storage. European Food Research and Technology 237(3): 309-314.

Scavnicar, A., Rogelj, I., Kocar, D., Kose, S. \& Pompe, M. 2018. Determination of biogenic amines in cheese by ion chromatography with tandem mass spectrometry detection. Journal of AOAC International 101(5): 1542-1547.

Shao, P., Wang, J., Zhang, T.T. \& Sun, P.L. 2015. Determination of starch adulteration in Ganoderma lucidum polysaccharide by near infrared reflectance spectroscopy with partial least squares algorithm. Current Topics in Nutraceutical Research 13(4): 181-187.

Subedi, S. \& Fox, T.R. 2016. Predicting Loblolly pine site index from soil properties using partial least-squares regression. Forest Science 62(4): 449-456.

Tasev, K., Ivanova-Petropulos, V. \& Stefova, M. 2017 Ultra-performance liquid chromatographytriple quadruple mass spectrometry (UPLC-TQ/MS) for evaluation of biogenic amines in wine. Food Analytical
Methods 10(12): 4038-4048.

Tyszka, A., Pikus, G., Dabrowa, K. \& Jurczak, J. 2019. Latestage functionalization of (R)-BINOL-based diazacoronands and their chiral recognition of alpha-phenylethylamine hydrochlorides. Journal of Organic Chemistry 84(10): 6502-6507.

Wang, L., Xiong, Q., Guo, C.H., Li, M.L. \& Pu, X.M. 2017. Ultraviolet spectroscopy combined with chemometrics for simultaneous quantitative determination of 2,4,6-trinitrotoluene and its degraded products in environmental water sample. Chinese Journal of Analytical Chemistry 45(5): 754-761.

Wen, L.F., Zhang, N., Li, H.C., Huang, Q., Wu, X.R., Hao, X.Y., Wu, M.J., Ban, C.L. \& Zhao, J.H. 2017. Ternary liquid-liquid equilibrium for mixtures of water plus (+/-) alpha-Phenylethylamine plus n-Hexane at $\mathrm{T}=298.2,318.2$, and 333.2 K. Journal of Chemical and Engineering Dato 62(7): 1819-1824.

Xia, L. 2017. Analysis of partial least squares modeling and multi-collinearity ability. Agro Food Industry Hi-Tech 28(1): 885-889.

Yan, K., Yuan, Z.W., Goldberg, S., Gao, W., Ostermann, A., Xu, J.C., Zhang, F.S. \& Elser, J. 2019. Phosphorus mitigation remains critical in water protection: A review and metaanalysis from one of China's most eutrophicated lakes. Science of The Total Environment 689: 1336-1347.

Ye, S., Chen, X., Dong, D.M., Wang, J.J., Wang, X.Q. \& Wang, F.Y. 2018. Rapid determination of water COD using laserinduced breakdown spectroscopy coupled with partial least-squares and random forest. Analytical Methods 10(40): 4879-4885.

Yu, L.M., Zhao, K.J., Wang, S.S., Wang, X. \& Lu, B. 2018. Gas chromatography/mass spectrometry based metabolomic study in a murine model of irritable bowel syndrome. World Journal of Gastroenterology 24(8): 894 904.

Zamora, R., Navarro, J.L. \& Hidalgo, F.J. 2018. Structureactivity relationship (SAR) of phenolics for the inhibition of 2-phenylethylamine formation in model systems involving phenylalanine and the 13-hydroperoxide of linoleic acid. Journal of Agricultural and Food Chemistry 66(51): 13503-13512.

Zappi, A., Maini, L., Galimberti, G., Caliandro, R. \& Melucci, D. 2019. Quantifying API polymorphs in formulations using X-ray powder diffraction and multivariate standard addition method combined with net analyte signal analysis. European Journal of Pharmaceutical Sciences 130: 36-43.

Zhou, Z., Li, Y., Zhang, Q., Shi, X.Y., Wu, Z.S. \& Qiao, Y.J. 2016. Comparison of ensemble strategies in online NIR for monitoring the extraction process of pericarpium citri reticulatae based on different variable selections. Planta Medica 82(1-2): 154-162.

State Key Laboratory of Electrical Insulation \& Power Equipment Xi'an Jiaotong University

No. 28 Xianning West Road

Xi'an, Shaanxi 710049

China

*Corresponding author; email: tongangxin@stu.xjtu.edu.cn

Received: 29 November 2019

Accepted: 1 April 2020 